\title{
PODRECCZNIKI DO NAUKI ISLAMU UŻYWANE PRZEZ MUZUŁMAŃSKI ZWIĄZEK RELIGIJNY W RP A SPECYFIKA MUZUŁMAŃSKIEJ EDUKACJI RELIGIJNEJ W POLSCE - MIĘDZY POLSKĄ A ŚWIATEM MUZUŁMAŃSKIM ${ }^{1}$
}

Streszczenie: Muzułmański Związek Religijny (MZR) jest najstarszą organizacją muzułmańską Polsce - został założony przez Tatarów - muzułmanów polsko-litewskich w 1925 roku. Po wprowadzeniu nauki religii muzułmańskiej do szkół w 1919 roku i po przywróceniu jej tam w 1992 roku jednym z głównych problemów zawsze był brak odpowiednich podręczników do nauki tego przedmiotu.

Mimo że niektóre nowe podręczniki zostały opublikowane po 1990 roku, nie obejmują one całego programu edukacji religijnej, a liczba egzemplarzy jest niewystarczająca, dlatego też podręczniki sprzed 1939 roku są nadal w użyciu, nawet jeśli są przestarzałe. Większość nowych podręczników, opublikowanych w ostatnich latach, to tłumaczenia z języków obcych $-\mathrm{z}$ bośniackiego, tureckiego (przez rosyjski lub angielski) lub arabskiego.

Artykuł omawia używane przed II wojną światową, obecnie przez nauczycieli MZR, podręczniki do nauki religii muzułmańskiej, koncentrując się na ich pochodzeniu, formie i roli języka arabskiego, a także metodyce jego nauczania.

Słowa kluczowe: nauka religii muzułmańskiej; muzułmańskie podręczniki; Tatarzy; islam w Polsce; język arabski.

\section{Wprowadzenie - podręczniki do nauki religii muzułmańskiej w Europie}

Muzułmańska edukacja religijna to jedno z zagadnień związanych z obecnością i życiem religijnym wyznawców islamu w Europie. Jest jej kilka modeli od powszechnego nauczania w szkołach publicznych po zajęcia w meczetach

1 Publikacja powstała w ramach programu Ministra Nauki i Szkolnictwa Wyższego pod nazwą „Narodowy Program Rozwoju Humanistyki”, realizowanego w latach 2016-2019 (projekt nr 2bH 15015683$)$. 
i centrach muzułmańskich w ramach tzw. szkółek niedzielnych (Nalborczyk 2018). Zagadnieniu temu poświęca się coraz więcej publikacji, które od problematyki ogólnej przechodzą do coraz bardziej szczegółowej, jak np. wykształcenie imamów i nauczycieli. Na pewno prekursorem w tej dziedzinie jest Ednan Aslan ${ }^{2}$, twórca kierunku „muzułmańska pedagogika religijna” na Uniwersytecie Wiedeńskim³. Pod jego redakcją ukazało się wiele pozycji książkowych poświęconych różnym aspektom nauczania religii muzułmańskiej w Europie (Aslan, Hermansen 2015; Aslan, Rausch 2018; Aslan, Windisch 2012). Temat ten jest omawiany także w innych publikacjach, np. w doktoracie Mouhanada Khorchide (2008) pt. Der islamische Religionsunterricht zwischen Integration und Parallelgesellschaft. Einstellungen der islamischen ReligionslehrerInnen an öffentlichen Schulen 4 czy Irki-Christin Mohr (2005) pt. Islamischer Religionsunterricht in Europa. Lehrtexte als Instrumente muslimischer Selbstverortung im Vergleich5, w corocznych raportach ze wszystkich państw europejskich w Yearbook of Muslims in Europe $e^{6}$, a najnowszą pozycją w tej dziedzinie jest praca zbiorowa pt. European Perspectives on Islamic Education and Public Schooling, wydana pod redakcją Jenny Berglund (2018) z Uniwersytetu Sztokholmskiego ${ }^{7}$.

Jednym z zagadnień związanych z muzułmańską edukacją religijną w Europie są podręczniki do nauki islamu. Różnią się one od tych stosowanych w najbardziej rozpowszechnionej na naszym kontynencie katechezie chrześcijańskiej przede wszystkim tym, że występuje w nich nauczanie języka arabskiego oraz czytania Koranu, świętej księgi muzułmanów. Koran według muzułmanów został zesłany w VII wieku prorokowi Mahometowi w języku arabskim i w tym języku należy go recytować w celach liturgicznych (Danecki 1997, s. 79) ${ }^{8}$. Obowiązkowa modlitwa muzułmanów (arab. salat) jest także odmawiana w języku arabskim (Rippin 2012, s. 107-108), zatem uczniowie uczęszczający na lekcje religii muzułmańskiej, aby opanować tę modlitwę, muszą osiągnąć pewną kompetencję w języku arabskim.

2 Jego doktorat zatytułowany Religiöse Erziehung der muslimischen Kinder in Österreich und Deutschland z 1997 roku, obroniony na Uniwersytecie w Klagenfurcie (Austria), ukazał się drukiem w roku 1998.

3 Od 2006 roku ten kierunek działa na Wydziale Filozofii i Pedagogiki (niem. Institut für Bildungswissenschaft, Fakultät für Philosophie und Bildungswissenschaft), a od 2017 roku w ramach Instytutu Teologicznych Studiów Muzułmańskich (niem. Institut für IslamischTheologische Studien, Philologisch-Kulturwissenschaftliche Fakultät)..

4 Doktorat ten został opublikowany - por. Khorchide (2009).

5 Doktorat ten został opublikowany - por. Mohr (2006).

6 Od 2009 roku co roku kolejny tom ukazuje się w wydawnictwie Brill, w roku 2019 ukazał się już 11 tom.

7 Jenny Berglund też zajmuje się tą problematyką od dłuższego czasu - np. Berglund (2010).

8 Przekłady na inne języki są dozwolone, ale tylko jako środek pomocniczy dla zrozumienia treści - klasyczny język arabski, który występuje w Koranie (Danecki 1997, s. 64-65, 79-80), jest wieloznaczny i każde tłumaczenie jest interpretacją, gdyż z wielu możliwych znaczeń dopuszcza jedno. 
Inną cechą odróżniającą podręczniki religii muzułmańskiej od tych do katechezy chrześcijańskiej, szczególnie w Europie zachodniej, jest fakt, że społeczności muzułmańskie są tam pochodzenia imigranckiego, o stosunkowo krótkiej historii - od przełomu lat 6o. i 70. XX wieku. Dlatego znacznie krótsza jest też tradycja korzystania $\mathrm{z}$ takich podręczników i w wielu miejscach nie zdążyło się wykształcić dość specjalistów, imamów i nauczycieli religii (Aslan 2012, s. 59-60), aby takie podręczniki przygotować. Oczywiście w Europie środkowej, południowej i wschodniej, gdzie zamieszkują tradycyjne społeczności muzułmańskie, których historia jest znacznie wcześniejsza niż połowa XX wieku (Nalborczyk 2018; Račius, Zhelyazkova 2018), podręczniki do nauki religii muzułmańskiej pojawiły się już wcześniej, np. w Albanii w 1919 roku podręcznik zatytułowany Muslimania Hafiza Alego Korçy, a w roku 1920 Dij'e fesë myslimane (alb. Wiedza o religii muzułmańskiej) autorstwa Hafiza Xhaferriego; w sumie do 1929 roku ukazało około 10 podręczników (Zekaj 2011, s. 42-43).

Zagadnieniu muzułmańskich podręczników do nauki religii nie poświęcano dotąd jednak wiele uwagi w literaturze przedmiotu. Do dnia dzisiejszego najbardziej obszerną jest pozycja z 2011 roku Islamic textbooks and curricula in Europe, pod redakcją wspomnianego już E. Aslana (2011), która skupia się głównie na sytuacji w państwach Europy środkowej i południowo-wschodniej, choć zawiera także teksty na temat podręczników używanych w Niemczech czy Hiszpanii.

$\mathrm{Z}$ tego powodu warto przyjrzeć się podręcznikom do nauki islamu używanym w Polsce, gdyż mają one stosunkowo długą tradycję - pierwsze z nich ukazały się w latach 20. XX wieku i do niedawna były nadal w użyciu, chociaż od kilku lat ukazują się nowe. Można zatem przeanalizować, co zmieniło się w ciągu tego czasu, a co pozostało niezmienne. Dlatego w niniejszym artykule omówiona zostanie zawartość, forma i pochodzenie podręczników używanych przez Muzułmański Związek Religijny w RP, który powstał w 1925 roku i ma najdłuższą tradycję nauczania islamu oraz wydawania pomocy naukowych?

\section{Muzułmański Związek Religijny i nauczanie religii}

Historia obecności islamu na ziemiach współczesnej Polski sięga roku 1679, kiedy Jan III Sobieski nadał muzułmańskim Tatarom ziemie na Podlasiu w zamian za niezapłacony żołd (Sobczak 1984, s. 34-37). Od tego czasu funkcjonowanie religii muzułmańskiej było związane z ramami prawnymi, jakie obowiązywały w danym momencie na tym obszarze (Nalborczyk, Borecki 2011).

Przed XX wiekiem muzułmańską edukacją religijną zajmowali się imamowie w lokalnych meczetach (Konopacki 2010, s. 198), a nauka obejmowała głównie język arabski, wykonywanie modlitwy i czytanie Koranu (Tyszkiewicz 2008, s. 156).

9 Inne muzułmańskie związki wyznaniowe prowadzą nauczanie religii dopiero od początku XXI wieku - jest to np. Liga Muzułmańska, zarejestrowana w 2004 roku. 
Jednak dzieci z rodzin żyjących poza gęstym osadnictwem tatarskim bardzo często nie otrzymywały żadnego wykształcenia religijnego poza wiedzą przekazaną przez rodziców (Wróblewska 2012, s. 18-19). Teologię muzułmańską studiowali polscy Tatarzy w Kazaniu, Symferopolu i Petersburgu - tereny zamieszkane przez nich znalazły się w XIX wieku, w następstwie rozbiorów, pod panowaniem rosyjskim (Miśkiewicz 1990, s. 84).

Po odzyskaniu przez Polskę niepodległości nauczanie religii zostało wprowadzone do szkół publicznych na terenach zamieszkanych przez muzułmańskich Tatarów w 1919 roku. W każdej z 19 wspólnot religijnych istniały tylko szkoły religijne dla dzieci w wieku od 6 do 8 lat - po jednej na każdą gminę (Mizgalski 1998, s. 106-107), w których uczono, jak pisać po arabsku i recytować Koran oraz modlić się w tym języku (Kryczyński 2000 [1938], s. 213-215). W konsekwencji większość muzułmańskich dzieci tatarskich uczęszczała do szkół publicznych i otrzymywała tam edukację religijną, głównie w klasach międzyszkolnych, chociaż także w domach prywatnych (Wróblewska 2012, s. 52 i n.), a państwo w znaczącym zakresie subsydiowało tę naukę (Mizgalski 1998, s. 108).

Nauczanie religii dla uczniów należących do kościołów i wspólnot religijnych uznanych przez państwo było w tym okresie obowiązkowe w szkołach podstawowych i średnich. Jedną z takich uznanych społeczności religijnych byli muzułmanie, reprezentowani przez Muzułmański Związek Religijny w Rzeczypospolitej Polskiej (MZR), założony w 1925 roku. Na czele Związku stał mufti, dr Jakub Szynkiewicz, a 21 kwietnia 1936 roku weszła w życie ustawa określająca stosunki państwa z MZR (Sobczak 2004, s. 201). To właśnie dzięki niej islam stał się religią oficjalnie uznaną przez państwo polskie (Miśkiewicz 1990, s. 53-54). Zgodnie z nią mufti nadzorował nauczanie islamu w szkołach publicznych oraz wyznaczał nauczycieli. Art. 52 ustawy stanowił, że każdy imam mógł nauczać religii muzułmańskiej w publicznej szkole na terenie swojej lokalnej gminy, a art. 32, że nauka była obowiązkowa każdy uczeń muzułmański do 18 roku życia musiał uczęszczać na lekcje islamu ${ }^{10}$.

Nie było muzułmańskich instytucji szkolnictwa wyższego. Ci, którzy chcieli studiować teologię islamu, musieli to zrobić za granicą. Niektórzy z nich studiowali w kairskim Uniwersytecie Al-Azhar (Woronowicz 1934, s. 148 i n.), a niektórzy w Sarajewie (Miśkiewicz 1990, s. 85; Wróblewska 2012, s. 75-80). W rezultacie istniały liczne grupy w miarę dobrze wykształconych imamów i hodżów, którzy mogli zapewnić edukację religijną w polskich szkołach.

Po 1945 roku w granicach państwa polskiego znalazła się tylko niewielka część terytoriów zamieszkanych przez Tatarów. W wyniku powojennych migracji znacząca część tatarskich muzułmanów zmuszona została do opuszczenia swoich ziem rodzinnych na Wileńszczyźnie, a przez przymusowe osiedlanie na Ziemiach Zachodnich byli rozproszeni, pozbawieni infrastruktury - miejsc modlitwy,

10 Ustawa ta w stanie z 1936 roku obowiązuje do dzisiaj, choć część jej artykułów się zdezaktualizowała (Nalborczyk, Borecki 2011, s. 350-351). 
meczetów czy cmentarzy. W 1947 roku reaktywowano Muzułmański Związek Religijny, który do 1989 roku był nadzorowany przez państwo ${ }^{11}$. Nadal działa on na podstawie ustawy z 1936 roku i oficjalnie ma ponad pięć tys. członków.

Po II wojnie światowej Polska stała się państwem socjalistycznym, a edukacja religijna została uznana za wewnętrzną sprawę kościołów i wspólnot religijnych. Władze stopniowo próbowały usunąć lekcje religii ze szkół publicznych, zaczynając od uczynienia z religii przedmiotu nieobowiązkowego (Konopka 1995, s 16 i n.), a od 1961 roku nauczanie religii stało się zadaniem wspólnot religijnych, takich jak parafie (Konopka 1995, s. 270-272). Dotyczyło to także MZR, choć ze względu na migracje powojenne i repatriację brakowało wykształconych imamów, nauczycieli religii (wielu Tatarów zginęło w czasie wojny lub udało się na emigrację), także podręczników. Z tego powodu obowiązki imamów przejęli Tatarzy wykształceni przed wojną i wykorzystywali oni przedwojenne materiały, mimo że zachowała się ich niewystarczająca liczba, zaś lekcje odbywały się głównie w domach prywatnych.

Po 1989 roku miały miejsce przemiany polityczne i zmiany ustroju państwa, które dotyczyły także relacji państwo-religie. Jedną z najbardziej znaczących zmian w sferze religijnej był w tym czasie powrót edukacji religijnej do szkół. Kwestię nauki religii w szkołach państwowych reguluje Ustawa o systemie oświaty z 7 września 1991 roku oraz Rozporządzenie ministra edukacji z 14 kwietnia 1992 roku. Religia każdej wspólnoty religijnej o uregulowanym statusie prawnym może być nauczana w szkołach publicznych i jest finansowana przez państwo ${ }^{12}$, w związku z czym muzułmańskie nauczanie religii może być prowadzone w polskich szkołach zarówno przez MZR, jak i przez inne muzułmańskie związki wyznaniowe obecne w rejestrze kościołów i związków wyznaniowych. Publiczna instytucja edukacyjna jest zobowiązana do zapewnienia nauki religii, jeśli uczęszcza do niej co najmniej siedmiu uczniów lub studentów danego wyznania. W przypadku mniejszej liczby uczniów lekcje religii odbywają się w ramach lekcji ogólnoszkolnych lub nauczania międzyszkolnego.

W 1992 roku Muzułmański Związek Religijny zaczął nauczać religii muzułmańskiej na zajęciach międzyszkolnych dla 200 uczniów w Białymstoku, największym skupisku Tatarów w Polsce, a także przez pewien czas w Suchowoli. Liczba uczniów w ciągu ostatnich lat systematycznie maleje: w 2010 roku było ich w Białymstoku około 6o-8o (Nalborczyk 2011, s. 185), a w 2016 już tylko 35 (Nalborczyk, Pędziwiatr 2018, s. 144). Wśród uczniów uczestniczących w tych zajęciach znajdują się obecnie również dzieci Tatarów krymskich, którzy przybyli jako uchodźcy do Polski w ciągu ostatnich kilku lat, a ich liczba wzrasta i MZR nadzoruje również edukację religijną w innej szkole w mieście dla 12 takich uczniów oraz w ośrodku dla uchodźców,

11 Więcej zob. Nalborczyk, Borecki (2011).

12 Artykuł 32 Ustawy z dnia 21 kwietnia 1936 roku o relacjach między państwem a MZR utracił moc prawną, ponieważ stwierdzał, że uczęszczanie na lekcje islamu jest obowiązkowe dla każdego ucznia muzułmańskiego - artykuł ten jest niezgodny z Konstytucją. 
gdzie 40 dzieci uczęszcza na lekcje islamu prowadzone przez czeczeńskiego imama. Całkowita liczba uczniów uczęszczających na lekcje islamu w mieście wynosi 87 (Nalborczyk, Pędziwiatr 2018, s. 144). W innych miastach nie ma wystarczającej liczby uczniów związanych z MZR, aby zorganizować edukację religijną jako klasę międzyszkolną ${ }^{13}$.

Nauczyciele wyznaczeni przez MZR muszą mieć odpowiednie wykształcenie. Są to zazwyczaj nauczyciele innych przedmiotów, mający wykształcenie pedagogiczne, którzy ukończyli specjalne kursy z teologii muzułmańskiej, zorganizowane przez Najwyższe Kolegium Muzułmańskie MZR i zdali egzaminy organizowane przez ten organ. Ich pensje są wypłacane przez państwo po podpisaniu umowy z władzami oświatowymi i dyrektorem danej szkoły, w której nauczają.

Od 2009 roku lekcje religii są prowadzone według programu nauczania, opracowanego przez zespół imamów, nauczycieli oraz muftiego Tomasza Miśkiewicza ${ }^{14}$, zgodnie z podstawowymi zasadami prowadzenia katechezy, osiągnięciami nauk pedagogicznych oraz wytycznymi kuratorium. Program ten obejmuje cztery poziomy nauczania , ale obejmuje uczniów przez cały okres nauki szkolnej, w wieku od 7 do 19 lat. Został on przedstawiony Ministerstwu Edukacji Narodowej zgodnie z obowiązującymi ${ }^{15}$.

\section{Polskie podręczniki do nauki religii muzułmańskiej do 1989 roku}

Do 1939 roku prowadzone były prace nad podręcznikami dla uczniów lokalnych szkół religijnych oraz pobierających naukę w szkołach publicznych. Pierwszym z nich był opublikowany w 1925 roku podręcznik języka arabskiego, oparty na tekstach Koranu, służący nauce biegłego czytania świętego tekstu. Został on wydany w 30 oddzielnych broszurach zwanych z arabskiego sufra, stąd potoczna nazwa „Suforka”, jak jest on nazywany przez Tatarów, choć oficjalny tytuł brzmi: Praktyczny podręcznik początkowego czytania po arabsku ${ }^{16}$. Broszury te zawierają wyłącznie teksty po arabsku bez żadnego prawie komentarza po polsku, co utrudniało naukę - nauczyciel musiał wyjaśnić znaczenie arabskich słów, a uczniowie przygotowywali własne zeszyty ze słownictwem i tłumaczeniem. W 1928 roku MZR opublikował liczącą 50 stron broszurę Historia proroków, która opisywała dzieje proroków staro- i nowotestamentowych, rozwój islamu oraz życie i misję

13 Poza Białymstokiem muzułmańska edukacja religijna jest prowadzona przez MZR w centrach religijnych (np. w Warszawie - do 2000 roku dla dzieci, a teraz głównie dla dorosłych konwertytów) i w meczetach (np. w Gdańsku - z przerwami ze względu na konflikt wokół imama, a potem remont budynku).

14 Jest to drugi po Szynkiewiczu mufti MZR, wybrany w 2004 roku, po raz pierwszy od II wojny światowej i śmierci Szynkiewicza w 1966 roku - stanowisko muftiego jest dożywotnie.

15 Szczegółowy opis tego programu - zob. Nalborczyk (2011, s. 186-189).

16 Wydawnictwo Muftjatu na Rzeczpospolitą Polską (pisownia oryg.) wydało wznowienia w latach 1928 i 1929, dodając nieco więcej tekstu w języku polskim. 
proroka Mahometa- dzięki temu opracowaniu uczniowie mieli poza wiedzą religijną otrzymać wzory osobowe do naśladowania. Pozycja ukazała się w Wilnie.

Dwa podręczniki poświęcone Koranowi zostały wydane po arabsku i po polsku w 1935 roku w Sarajewie. Pierwsza publikacja zatytułowana Tadžwid - nauka czytania Koranu, napisana przez imama Alego Smajkiewicza, liczyła 24 strony i służyła nauce czytania po arabsku dzięki praktycznym wskazówkom, zaś we wstępie opisana została struktura Koranu i jego historia. Druga to Wersety z Koranu, które zawierały po lewej stronie tekst arabski wybranych sur, a po prawej tłumaczenie na język polski, autorstwa muftiego Jakuba Szynkiewicza (Wróblewska 2012, s. 67). W 1937 roku absolwent Uniwersytetu Al-Azhar, Mustafa Aleksandrowicz, opublikował w Wilnie liczący 42 strony Krótki zarys religii Islamu (Kryczyński 1937, s. 11).

Edukacja młodych Tatarów w okresie międzywojennym nie obejmowała jedynie spraw religijnych, lecz także kulturalne i historyczne aspekty funkcjonowania tej mniejszości. Władze odpowiedzialne za edukację dostrzegły te szczególne potrzeby muzułmańskiej tatarskiej edukacji religijnej i kulturalnej, a dowodem na to jest licząca 45 stron książeczka Tatarzy $w$ Polsce, wydana przez kuratorium w Wilnie w 1936 roku. Broszura ta zawiera kompilację historii i charakterystyki muzułmańskiej mniejszości tatarskiej, a została opublikowana jako dodatek do państwowego czasopisma „Dziennik Urzędowy Kuratorium Okręgu Szkolnego Wileńskiego". Miał on zapewnić pomoc nauczycielom pracującym na obszarach o znacznej liczbie Tatarów, gdyż w krótkim wstępie Od redakcji czytamy: „Jak widać z zamieszczonego w niniejszej pracy wykresu, na ogólną liczbę 5425 Tatarów polskich - 5366 zamieszkuje w obrębie Wileńskiego Okręgu Szkolnego. Dlatego nauczycielstwo tutejsze, chcąc uwzględnić warunki lokalne przy wykonywaniu programu, nieraz będzie musiało wziąć pod uwagę również wychowanków tej narodowości, chlubnie zapisanej w dziejach naszego Państwa. Ponieważ bardziej są znane walki z hordami tatarskiemi, a mniej braterskie współżycie mieszone stuleciami z licznemi zastępami Tatarów, osiadłych w naszym kraju, pragniemy dostarczyć wiadomości o tem drugiem zagadnieniu i w tym celu wydajemy niniejszy tomik" (Tatarzy w Polsce 1936, s. 1) ${ }^{17}$.

Po II wojnie światowej do lat 9o. XX wieku wydawanie nowych podręczników było problemem nie tylko ze względu na mały zasób kadr, lecz także cenzurę czy rządowy przydział papieru. W trakcie nauki religii, prowadzonej głównie w domach prywatnych, korzystano z materiałów przedwojennych, które ulegały zniszczeniu i nie można ich było odtwarzać. Tylko jeden nowy podręcznik, Nauka o religii islamu i języka arabskiego, został przygotowany do użytku wewnętrznego na maszynie do powielania - najpierw polski tekst został napisany na maszynie do pisania, następnie tekst arabski dodano ręcznie i całość została skopiowane na powielaczu. Ten podręcznik zawiera również rysunki pokazujące, jak wykonywać

$17 \mathrm{~W}$ cytacie zachowano pisownię oryginalną. 
modlitwę. Był w użyciu przez dłuższy czas w ramach edukacyjnej działalności MZR, ale liczba jego egzemplarzy była zawsze niewystarczająca.

\section{Polskie podręczniki do nauki religii muzułmańskiej po 1989 roku}

Po upadku komunizmu wydawanie książek stało się w Polsce o wiele łatwiejsze. W przypadku podręczników do nauki islamu wykorzystano wtedy tłumaczenia z języków obcych. Pierwszy podręcznik opublikowany w 1990 roku, autorstwa Ghulama Sarwara, nosił tytuł Islam dla najmłodszych ${ }^{18}$ i został przetłumaczony z języka angielskiego przez Bogusława R. Zagórskiego, polskiego muzułmanina, absolwenta arabistyki i islamistyki. Ta niewielka książeczka, a właściwie broszura, jest interesującym przykładem ówczesnego podręcznika: druk jest kolorowy z tym że na każdej stronie oprócz koloru czarnego mamy tylko jeden inny kolor, obok tekstu jest dużo rysunków, ćwiczeń do wykonania itp. Wyrazy pochodzenia arabskiego podano w uproszczonej transkrypcji polskiej, a tekstów w alfabecie arabskim jest niewiele. Jednak liczba kopii zawsze była mała, a szczególnie od 2009 r., kiedy większość egzemplarzy spłonęła w będącej w trakcie budowy szkole koranicznej w Białymstoku.

Fragmenty powyższego podręcznika zostały opublikowane w internecie na blogu „Mali Muzułmanie” (dostępnym pod adresem: http://naukapoprzezzabawe. wordpress.com). Wersja internetowa ma inne, znacznie bardziej współczesne, kolorowe rysunki, ale ponieważ jest to nowe polskie tłumaczenie z oryginału angielskiego, zawiera sporo błędów w pisowni, interpunkcji i transkrypcji arabskich słów. Używa też arabskiego słowa Allah zamiast polskiego Bóg, użytego w pierwszym tłumaczeniu, co nie wydaje się dobrym zabiegiem, gdyż 'Allah' to w języku arabskim słowo ilah o znaczeniu 'bóg, bóstwo z prefiksem al-, będącym rodzajnikiem określonym ${ }^{19}$, co daje w tłumaczeniu znaczenie wyrazu „bóg” z rodzajnikiem określonym (jak po niemiecku der Gott), a zatem w języku polskim oznacza Boga (pisanego wielką literą).

Pierwszym podręcznikiem opublikowanym jeszcze przed wprowadzeniu nauczania religii muzułmańskiej do szkół publicznych była Nauka o religii islamu i języka arabskiego - został on wydany w Libanie w 1990 roku; autor jest nieznany. Dużo jest w tej publikacji tekstu polskiego, wyrazy arabskie są w zasadzie w transkrypcji uproszczonej (z pewnymi odstępstwami), choć tu znowu używany jest wyraz Allah na określenie Boga. W części z reprodukcjami pisma arabskiego występują fragmenty po turecku. Ten podręcznik zawiera również obrazki pokazujące, jak się

18 Wydawca to WAMY - Światowe Zgromadzenie Młodzieży Muzułmańskiej, miejsce wydania Wiedeń-Warszawa, książkę drukowano w Polsce. Jest to tłumaczenie książki Islam for younger people, wydanej przez The Muslim Educational Trust w roku 1981.

19 Al-(i)lah - 'i’ wypada (nie jest nawet zapisywane) ze względu na specyfikę fonologiczną języka arabskiego. 
modlić czy dokonać ablucji przed modlitwą. Był używany tylko przez Muzułmański Związek Religijny, ale liczba egzemplarzy była niewystarczająca (Nalborczyk 2011, s. 191). Pierwszymi podręcznikami opublikowanymi po wprowadzeniu nauczania islamu do szkół publicznych były wydane w 1992 roku Islam - moja wiara autorstwa warszawskiego imama Nusreta Kujrakovicia (pochodził z Bośni) oraz Jak czytać Kur'an i o dziennych modlitwach $w$ islamie, pozycja oryginalnie wydana w języku bośniackim, a przetłumaczona przez N. Kujrakovicia. Obie te książki zawierają instrukcje wraz z obrazkami, jak wykonywać modlitwę, ale w tej pierwszej fragmenty $\mathrm{w}$ języku arabskim zapisane są w transkrypcji na alfabet łaciński z wyraźnymi naleciałościami tureckimi. Druga zawiera teksty pisane alfabetem arabskim, ale także i w niej obecne są wpływy tureckie w zapisie alfabetem łacińskim sposobu czytania tekstu arabskiego, choć, co ciekawe, używane jest w tej publikacji polskie słowo 'Bóg'.

\section{Podręczniki do nauki religii muzułmańskiej wydawane przez MZR od 2017 roku}

W drugiej dekadzie XXI wieku MZR nawiązał bliską współpracę z Turcją, która przejawia się m.in. w finansowaniu przez turecką rządową agencję TİKA przebudowy sal modlitw czy porządkowania cmentarzy. Współpraca ta widoczna jest także bowiem wydawaniu podręczników do nauki religii, przeznaczonych dla młodszych dzieci. W 2017 roku ukazała się seria sześciu podręczników: 1. Poznaje swoja religię; 2. Poznaję swojego Proroka; 3. Moja księga Koran; 4. Moje prośby do Boga; 5. Uczę się czcić Boga i 6. Uczę się etyki. Pierwotnie zostały one wydane po turecku przez Diyanet, czyli tureckie Ministerstwo ds. Religii (tur. Diyanet İşleri Başkanlığı), ale na polski przełożone zostały wersje rosyjskojęzyczne i angielskojęzyczne ${ }^{20}$ (tłumaczy było kilku). Nie występuje w tych książkach prawie w ogóle alfabet arabski, zaś fragmenty w języku arabskim zapisane zostały w transkrypcji uproszczonej, choć niekonsekwentnie i z błędami (arabska litera „waw” jako „,”, a nie „w”, np. al-Asład, choć zdarza się Hawwa czy Waraka ${ }^{21}$ ), widoczne są także naleciałości z języka tureckiego np. kerim zamiast karim (arab. „szlachetny”) o Koranie. Jednak wyraźnie nauka tu nie zaczyna się od alfabetu i języka arabskiego, ale od zagadnień prostszych, zrozumiałych dla dzieci. Wersety koraniczne występują w najlepszym polskim przekładzie Józefa Bielawskiego, choć nigdzie tej informacji nie odnotowano. Szata graficzna jest nowoczesna, wszystkie rysunki są kolorowe, dostosowane do europejskiego kontekstu (np. dorosłe kobiety nie noszą hidżabu), a tekst łatwy w odbiorze dla dzieci. Niestety, wymiennie stosowany jest wyraz Bóg i Allah, z przewagą tego ostatniego.

\footnotetext{
20 Polscy Tatarzy nie posługują się językiem tureckim.

21 Inne: Bismillahir rahaminr rahim - powinno być: Bi-smi (A)llahi r-rahmani r-rahim.
} 
Kolejna seria książek dla dzieci, także oryginalnie wydana przez Diyanet i tłumaczona na język polski z rosyjskiego, to: Moja wspaniała religia. Składa się z czterech tomów, wydanych w latach 2017-2018: 1. Uczę się czcić Boga 1; 2. Uczę się czcić Boga 2; 3. Poznaje podstawy wiary 1; 4. Poznaje podstawy wiary 2. Forma graficzna tych podręczników jest atrakcyjna, choć więcej tu elementów tureckich lub szerzej wschodnich, także nie ma prawie alfabetu arabskiego, a transkrypcja z języka arabskiego wygląda identycznie jak w wyżej omówionej serii książek.

Następny, lecz o innym charakterze, podręcznik Diyanetu przełożony na polski za pośrednictwem angielskiego to Nauka czytania Koranu, wydana w 2018 roku. W książce tej pojawia się oczywiście już alfabet arabski i objaśnienia, jak go czytać, przy czym dla jasności używa się kolorowych liter. Transkrypcja z języka arabskiego wygląda identycznie jak w powyżej omówionych podręcznikach.

Znacznie lepiej wypada wydana także w 2018 roku książka 40 hadisów w opowiadaniach - zbiór historyjek ilustrujących 40 wypowiedzi proroka Mahometa, wziętych z jego tradycji. To także przekład z języka rosyjskiego przy języku tureckim oryginału. Transkrypcja jest stosowana konsekwentnie i w tekście polskim występuje słowo 'Bóg”. Forma graficzna jest mniej atrakcyjna, a druk czarno-biały.

Najlepsza pod względem merytorycznym i formalnym jest Prolegomena do modlitwy Abu al-Lajsa as-Samarkandiego, przełożona na język polski bezpośrednio z języka arabskiego przez znanego polskiego arabistę, Marka Dziekana. Zawiera ona wyjaśnienia i wskazówki, jak należy wykonywać modlitwę, a także teksty modlitw w języku polskim. Wyrazy i zwroty z języka arabskiego używane są w poprawnej, konsekwentnej uproszczonej transkrypcji polskiej, a w tekście polskim występuje słowo „Bóg”.

\section{Podsumowanie}

Nauka religii muzułmańskiej ma w Polsce długą tradycję, tak długą, jak obecność na polskich ziemiach islamu i wyznających go muzułmanów, czyli Tatarów polsko-litewskich. Jednak do szkół publicznych została wprowadzona dopiero w 1919 roku, a od 1925 roku, czyli od roku swojego powstania, prowadzi ją Muzułmański Związek Religijny w RP. Po II wojnie światowej nauczanie religii wyprowadzono ze szkół, dokąd wróciła ona w 1992 roku.

Mimo że przez cały ten czas przedstawiciele muzułmańskiej społeczności tatarskiej podejmowali starania o stworzenie podręczników do nauki religii, to brak odpowiednich, nowoczesnych podręczników był cały czas głównym problemem w tej dziedzinie. Ze względu na rolę języka arabskiego w religii i liturgii muzułmańskiej konieczne było używanie alfabetu arabskiego, co nie w każdym okresie było łatwe technicznie. Z drugiej strony ze względu na niewielką liczebność polskiej mniejszości tatarsko-muzułmańskiej często brakowało odpowiednio wykształconych osób, które mogły by takie podręczniki przygotować. Dlatego po przywróceniu wolności publikacji w 1989 roku, wydawane były głównie przekłady 
podręczników - z języka angielskiego, bośniackiego, a ostatnio nawet z tureckiego, choć za pośrednictwem języków rosyjskiego i angielskiego. Sposób obchodzenia się z transkrypcją języka arabskiego jest dowodem na słabą znajomość jej zasad przez redaktorów, podobnie jak zamienne stosowanie wyrazów „Bóg” i „Allah”. O ile tradycyjne podręczniki polskich Tatarów do nauki religii zaczynają naukę od alfabetu arabskiego, czytania Koranu i recytacji modlitw po arabsku, a także od nauki rytuałów modlitwy, w nowych podręcznikach, importowanych z Turcji, nauka nie zaczyna się od poznawania alfabetu i języka arabskiego, lecz od zagadnień prostszych, zrozumiałych dla dzieci. Jednak i te nowe podręczniki nie obejmują całego kursu nauczania religii muzułmańskiej, dlatego wciąż w użyciu są podręczniki przedwojenne, jak również publikacje polskich islamologów i arabistów, np. Koran w przekładzie Józefa Bielawskiego, Podstawowe wiadomości o islamie Janusza Daneckiego itp. czy fragmenty podręczników do katechezy katolickiej.

\section{Bibliografia}

Aslan E. (2012). Training of imams and teachers in Europe. W: Aslan E., Windisch $\mathrm{Z}$. (red.). The training of imams and teachers for Islamic education in Europe. Frankfurt: Peter Lang.

Berglund J. (2010). Teaching Islam: Islamic Religious Education in Sweden. MünsterNew York: Waxmann.

European Perspectives on Islamic Education and Public Schooling. (2018). Berglund J. (red.). Equinox: Sheffield.

Danecki J. (2011). Podstawowe wiadomości o islamie. Warszawa: Wydawnictwo Akademickie Dialog.

Islam a świat. (2004) Baecker R., Kitab Sh. (red.). Toruń: Mado

Islam and citizenship education. (2015). Aslan E., Hermansen M. (red.). Wiesbaden: Springer.

Islamic leadership in the European lands of the former Ottoman and Russian empires. Legacy, challenges and change. (2018). Račius E., Zhelyazkova A. (red.). Leiden: Brill.

Islamic textbooks and curricula in Europe. (2011). Aslan E. (red.). Frankfurt: Peter Lang.

Khorchide M. (2009). Der islamische Religionsunterricht zwischen Integration und Parallelgesellschaft. Einstellungen der islamischen ReligionslehrerInnen an öffentlichen Schulen. Wiesbaden: VS Verlag für Sozialwissenschaften.

Konopacki A. (2010). Życie religijne Tatarów na ziemiach Wielkiego Księstwa Litewskiego w XVI-XIX w. Warszawa: Wydawnictwo Uniwersytetu Warszawskiego.

Konopka H. (1995). Religia w szkołach Polski Ludowej. Białystok: Dział Wydawnictw Filii UW.

Kryczyński S. (200o [1938]). Tatarzy litewscy. Próba monografii historyczno-etnograficznej. Gdańsk: Rocznik Tatarów Polskich. 
Kryczyński L. (1937). Przegląd literatury o islamie i Tatarach za r. 1937. „Przegląd Islamski”, nr 6/4, s. 11-16.

Miśkiewicz A. (1990). Tatarzy Polscy 1918-1939. Warszawa: PWN.

Mizgalski J. (1998). Oświata wśród Tatarów w Polsce międzywojennej. „Prace Naukowe Wyższej Szkoły Pedagogicznej w Częstochowie. Zeszyty Historyczne”, nr 5, s. 101-109.

Mohr I.-Ch. (2006). Islamischer Religionsunterricht in Europa. Lehrtexte als Intrumente muslimischer Selbstverortung im Vergleich. Bielefeld: transcript.

Nalborczyk A.S. (2018). Islam in Mittel- und Osteuropa: Geschichte und Gegenwart: Polen, Litauen, Weißrussland, Lettland, Estland. „Pastoraltheologische Hefte”, nr 11, s. 23-43.

Nalborczyk A.S. (2011). Islamic religious education in Poland - curricula and textbooks. W: Aslan E. (red.). Islamic textbooks and curricula in Europe. Frankfurt: Peter Lang.

Nalborczyk A.S., Pędziwiatr K. (2018). Between old traditions and new diversities: Islamic religious education in Poland. W: Berglund J. (red.). European perspectives on Islamic education and public schooling. Sheffield: Equinox Publishing.

Nalborczyk A.S., Borecki P. (2011). Relations between Islam and the state in Poland: the legal position of Polish Muslims. "Islam and Christian-Muslim Relations”, nr 22/3, s. 343-359.

Religious education: Between radicalism and tolerance. (2018). Aslan E., Rausch M. (red.). Wiesbaden: Springer.

Rippin A. (2012). Muslims: their religious beliefs and practices. London-New York: Routledge.

Sobczak J. (2004). Położenie prawne polskich wyznawców islamu. W: Baecker R., Kitab Sh. (red.). Islam a świat. Toruń: Mado.

Sobczak J. (1984). Położenie prawne ludności tatarskiej w Wielkim Księstwie Litewskim. Warszawa-Poznań: PWN.

Tatarzy w Polsce. Dodatek nr 19 pod red. Dr-a W. Arcimowicza (1936). „Dziennik Urzędowy Kuratorium Okręgu Szkolnego Wileńskiego", nr 2.

The training of imams and teachers for Islamic education in Europe. (2012) Aslan E., Windisch Z. (red.). Frankfurt: Peter Lang.

Tyszkiewicz J. (2008). Tatarzy w Polsce i Europie. Fragmenty dziejów. Pułtusk: AH.

Woronowicz A. (1934). Polacy-muzutmanie na Uniwersytecie Al-Azhar w Kairze. „Wschód-Orient”, nr 2-4, s. 148-155.

Wróblewska U. (2012). Oświata Tatarów w Drugiej Rzeczypospolitej. Warszawa: Semper.

Yearbook of Muslims in Europe. (2009-2018), vol. 1-10. Leiden: Brill.

Zekaj R. (2011). Tradition, actuality and perspectives on Islamic education in Albania. W: Aslan E. (red.). Islamic textbooks and curricula in Europe. Frankfurt: Peter Lang. 


\title{
ISLAMIC RELIGIOUS EDUCATION TEXTBOOKS USED BY THE MUSLIM RELIGIOUS UNION AND THE CHARACTER OF ISLAMIC RELIGIOUS EDUCATION IN POLAND - BETWEEN POLAND AND THE MUSLIM WORLD
}

\begin{abstract}
The MZR is the oldest Islamic religious organization in Poland established by Polish-Lithuanian Muslim Tatars in 1925. After the introduction of Islamic religious education to public schools in 1919 and reintroduction in 1992, the lack of proper, modern textbooks seems to be one of the main problems. Even though some new textbooks have been published after 1990, they do not cover the whole course of Islamic religious education and the number of copies is insufficient, so the pre-1939 textbooks are still in use, even though they are outdated. Most of the new textbooks published in recent years are translations from foreign languages including Bosnian, Turkish (through Russian or English) or Arabic.

The paper will discuss the contents of textbooks used before the WW2 and currently by the MZR, focusing on their origin, form and role of the Arabic language as well as teaching methods.
\end{abstract}

Keywords: Islamic religious education; Islamic textbooks; Tatars' Islam in Poland; Arabic language.

Agata S. Nalborczyk - doktor habilitowana religioznawstwa (islamistyka), iranistka i arabistka, kierownik Zakładu Islamu Europejskiego Wydziału Orientalistycznego Uniwersytetu Warszawskiego. Zajmuje się m.in. mniejszościami muzułmańskimi w Europie, szczególnie ich statusem prawnym i historią obecności, Tatarami polsko-litewskimi, zagadnieniami gender w islamie, w tym feminizmem muzułmańskim, kontaktami muzułmańsko-chrześcijańskimi oraz obrazem islamu w Europie. Redaktorka serii "Annotated Legal Documents on Islam in Europe” (Brill), członek redakcji czasopisma „Sociology of Religion”, „Studia Religiologica” oraz „Islamology. Journal for Studies of Islam and Muslim Societies". Należy do Komitetu Nauk Orientalistycznych PAN (kadencja 2015-2020) oraz Scientific Advisory Board przy Erlangen Centre for Islam and Law in Europe (Friedrich-Alexander Universität Erlangen-Nürnberg, Niemcy). Adres korespondencyjny: Wydział Orientalistyczny, Uniwersytet Warszawski, ul. Krakowskie Przedmieście 26/28, o0-927 Warszawa. Adres e-mailowy: a.nalborczyk@uw.edu.pl. 